International Journal of Current Advanced Research

ISSN: O: 2319-6475, ISSN: P: 2319 - 6505, Impact Factor: SJIF: 5.995

Available Online at www.journalijcar.org

Volume 6; Issue 3; March 2017; Page No. 2524-2529

DOI: http://dx.doi.org/10.24327/ijcar.2017.2529.0042

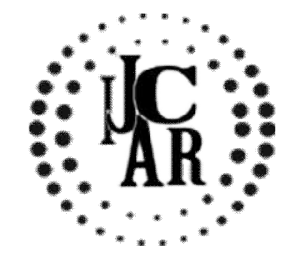

Research Article

\title{
SCREENING OF PHYTOCHEMICALS AND BIOACTIVE COMPOUNDS IN PUNICA GRANATUM PEEL TO EVALUATE ITS HEMATOLOGICAL POTENTIAL
}

\author{
Shikha Rana., Savita Dixit* and Alok Mittal
}

Maulana Azad National Institute of Technology, Bhopal

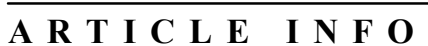

\section{Article History:}

Received $11^{\text {th }}$ December, 2016

Received in revised form $19^{\text {th }}$ January, 2017

Accepted $8^{\text {th }}$ February, 2017

Published online $28^{\text {th }}$ March, 2017

\section{Key words:}

Pomegranate peel, antioxidant activity, DPPH free radical scavenging, nitric oxide radical scavenging, hemoglobin booster.

\begin{abstract}
A B S T R A C T
Background: Pomegranate is the most significant tree which has been domesticated for incalculable human benefits and serves as a food medicine of great importance. Pomegranate has been found to have ethnomedical history and is a rich reservoir of phytochemicals. These are found to possess several chemicals and have immense economic value. Its various parts are exploited by pharmaceuticals and are considered as a powerhouse of energy due to its nutritive value.

Methods: The present study was carried out for phytochemical analysis in the hydroalcoholic pomegranate peel extracts. The phytochemical analysis and analysis of bioactive compounds are done, the pomegranate peel extracts are found to have carbohydrates, alkaloids, flavonoids, steroids, tannic acids and phenolic compounds. The antioxidant activity, DPPH free radical scavenging activity, nitric oxide radical scavenging activity was analyzed.

Results: For good health, the quality of blood should be maintained and for this antioxidant may be the key so as to protect the blood from oxidative stress. The results of various tests performed are compiled in various graphs and tables.

Conclusions: Thus, from the present study it is concluded that pomegranate peel is a rich source of phytochemicals and bioactive compounds such as antioxidants and so can be used for various pharmaceutical and therapeutic purposes like increase in hemoglobin count.
\end{abstract}

Copyright $₫ 2017$ Savita Dixit et al. This is an open access article distributed under the Creative Commons Attribution License, which permits unrestricted use, distribution, and reproduction in any medium, provided the original work is properly cited.

\section{INTRODUCTION}

Phytochemicals are found in plants and are non nutritive in nature but have certain disease preventing properties. They offer protection against pathogens and are not required by human beings for perpetuating life [Kokate CK et al 2006]. Phytochemicals work in many ways such as antioxidants which protect the cells from damage. These can stimulate certain enzymes and can reduce the risk of various ailments. These can also act as anti-bacterial and hormonal stimulant.

There are various pharmacological and epidemiological evidences which prove that plants contain biologically active components which offer various health benefits and also protects against degenerative ailments [Mutahar S, Shiban et $a l, 2012]$. The health benefits are often associated with plant phytochemicals as of consumption of higher levels of fruits and vegetables.

The phenolic compounds found in plants are found to exihibit various properties such as anti-allergic, anti-inflammatory,

*Corresponding author: Savita Dixit

Maulana Azad National Institute of Technology, Bhopal anti-microbial, antioxidant etc [Huang DO et al2005, Balasundram N et al 2006, Reddy $\mathrm{M}$ et al 2007]. Pomegranate is the most significant tree which has been domesticated for incalculable human benefits and serves as a food medicine of great importance. It has been widely used in Middle East, Iran and India for antimicrobial activities. Many researchers have conducted various experiments for studying phytochemicals present in pomegranate. These are found to possess several chemicals and have immense economic value. Its various parts are exploited by pharmaceuticals and are considered as a powerhouse of energy due to its nutritive value. Due to the presence of many phytochemicals it is also known as the 'super fruit.'[Sharma J et al.2010]

The fruit and its products are used anciently for diseases such as Stomachic, inflammation, fever, bronchitis, diarrhea, dysentery, vaginitis, urinary tract infections and others. Pomegranate peels are found to be effective against Malaria [Li Y et al 2006, Reddy M et al 2007, Iqbal S et al 2008]. Various pomegranate supplements are found in the market [Negi P and Jayaprakasha J. 2003]. Ellagic tannins and elagic acid are among the most potent antioxidants found in peel [Murthy KC et al 2002, Iqbal S et al 2008]. Antioxidants play an important role in the quality of our blood. Strong blood 


\section{Screening of phytochemicals and bioactive compounds in punica granatum peel to evaluate its hematological potential}

cells and vessels with adequate antioxidant capacity help maintain regular cholesterol levels essential for heart health helping keep heart diseases such as heart attacks etc at bay [http://healthforeversupplements.blogspot.in/2010/02/improve -blood-quality-lower-blood.html.Wednesday, February 10, 2010]. Pomegranate extracts are found to increase the hemoglobin count [Hemoglobin increase naturally Ayurveda Tips, 2016].

\section{Plant profile}

Botanical name: Punica granatum L

\section{Taxonomical classification}

Kingdom: Plantae

Division: Magnoliophyta

Class: Magnoliopsida

Subclass: Rosidae

Order: Myrtales

Family: Punicaceae

The major basic antioxidants or free radical scavengers from plant phenolics constitutes as a major group of compounds. These include stanins and flavonoids [Surya Prabha M et al 2013]. Whereas saponins behaves as cardio depressants and shows hypotensive properties [Olaleye MT.2007]. Glycosides are naturally cardio active drug and is used to treat heart failures [Brain FH et al 1985]. Thus the purpose for the present investigation was to evaluate the phytochemicals present in pomegranate peel using in vitro methods. The screening results are tabulated.

\section{MATERIALS AND METHODS}

The fresh pomegranate fruits were collected from the fruit market, Bittan Market, Bhopal. The fruits were washed and then disinfected. The peel was carefully removed from the seeds. These peels were then shade dried for 10 days.Then the pomegranate peels were grinded in the grinder. Then these are taken for extraction process
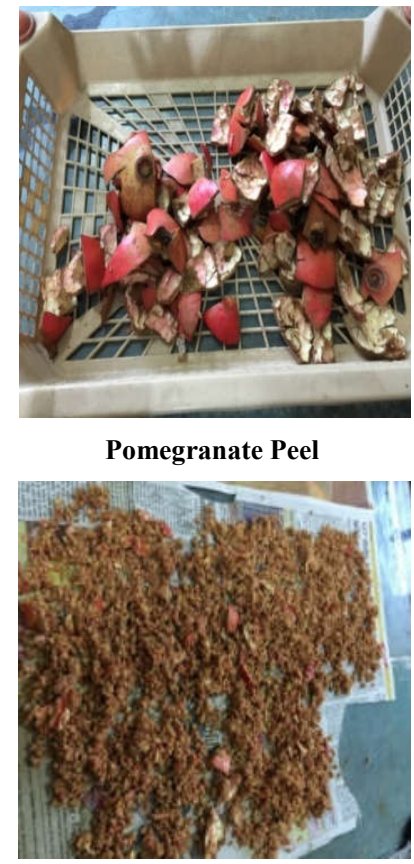

Grinded Pomegranate Peel

\section{Preparation of hydro alcoholic extract}

The powdered material is extracted with the help of Soxhlet apparatus. $200 \mathrm{ml}$ of the solvent is used in the ratio of 70:30 (methanol/water). A Soxhlet extraction is used when the desired compound has a limited solubility in a solvent, and the impurity is insoluble in that solvent. It allows for unmonitored and unmanaged operation while efficiently recycling a small amount of solvent to dissolve a larger amount of material.

$\begin{array}{lll}\text { Initial weight of Pomegranate peels } & = & 320 \text { grams } \\ \text { Weight after drying } & = & 65.984 \text { grams } \\ \text { Solvent system used } & = & \text { Hydro-alcoholic } \\ \text { system }(200 \mathrm{ml}) & & \\ \text { Percentage yield } & = & 30.04 \%\end{array}$

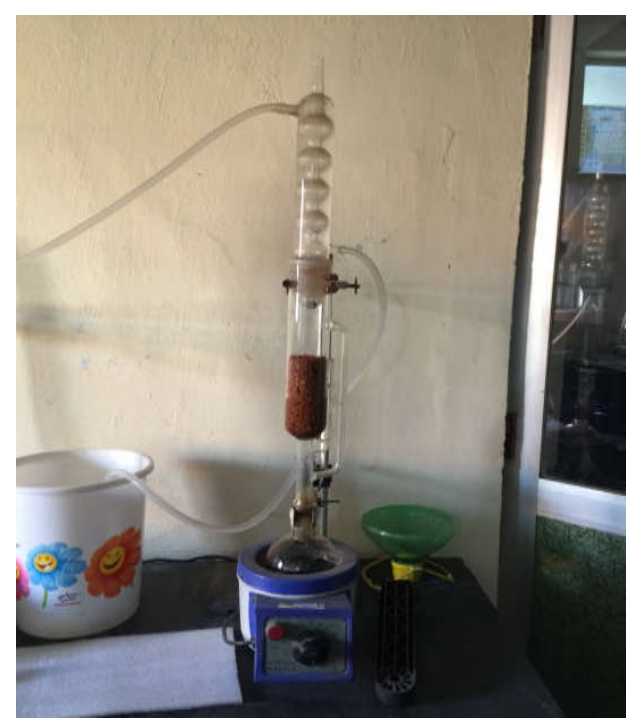

Figure 1 Extraction Process

\section{Phytochemical analysis}

The hydroalcoholic extract of Punicagranatum fruit peel were studied for their phytoconstituents using different phytochemical tests [Ayoola GA et.al 2008].

\section{Qualitative Phytochemical analysis}

The crucial starting point for assessing the pharmacological aspect of pomegranate is the i.dentification of the phytochemicals. The pomegranate peel extract was screened to identify the key families of phytochemicals. Following tests were performed for identification.

\section{Molisch test}

This test is performed to identify carbohydrates. In this $2.3 \mathrm{ml}$ of the extract was taken and 4 drops of naphthol in alcohol is added. This is then shaked well and conc. $\mathrm{H}_{2} \mathrm{SO}_{4}$ is then poured from the sides of the test tube.

\section{Test for Steroids}

This test is known as the Salkowiski test. In this $2 \mathrm{ml}$ of chloroform and $2 \mathrm{ml}$ of conc. $\mathrm{H}_{2} \mathrm{SO}_{4}$ are added to $2 \mathrm{ml}$ of the extract. This is then shaken well.

\section{Test for Flavanoids}

Take $2 \mathrm{ml}$ of test solution then add Small quantity of reduced lead acetate solution (10\%). 


\section{Millions Test}

2ml. solution and Million Reagent will mix properly

\section{Maeyer's Test}

Take 2- $3 \mathrm{ml}$. filtrate extract solution with few drops mayer reagent.

\section{Wagner's test}

2-3 ml. filtrate extract solution with few drops wagners reagent.

\section{Tannic acid and Phenolic tests}

Take 2-3ml. of aqueous or alcoholic extract add few drops for following reagent.

\section{Test for Sulphates}

With lead acetate reagent gives white ppt. will form that soluble in $\mathrm{NaOH}$ solution.

\section{Test for Chloride}

Take 5-7 ml. filterate plant extract solution and add 3-5 ml. lead acetate solution.

\section{Test for saponins}

Foam test - The extract and powder were mixed vigorously with water.

\begin{tabular}{cc}
\hline Reagent & Observation \\
\hline $5 \% \mathrm{FeCl}_{3}$ solution & Solution will appear deep blue black \\
colour. \\
Lead acetate solution $(10 \%)$. & Solution will form white ppt. \\
Gelatin solution $(10 \%)$ Solution & Solution will form white ppt. \\
Acetic acid solution. & Solution will appear red colour \\
Dilute iodine solution. & Solution will appear red colour \\
Dilute potassium permagnate & Solution will decolourizes its colour. \\
solution & \\
\hline
\end{tabular}

\section{Analysis of Bioactive Compounds}

\section{Total Flavonoid content}

A clean test tube was taken and $0.5 \mathrm{ml}$ of the sample (Extract) is added, containing $1.25 \mathrm{ml}$ of distilled water. Then $0.075 \mathrm{ml}$ of $5 \%$ sodium nitrite solution is added and allowed to stand for $5 \mathrm{~min}$. $0.15 \mathrm{ml}$ of $10 \%$ aluminium chloride is added, after $6 \mathrm{~min} 0.5 \mathrm{ml}$ of $1.0 \mathrm{M}$ sodium hydroxide was added and the mixture were diluted with another $0.275 \mathrm{ml}$ of distilled water. The absorbance of the mixture at $510 \mathrm{~nm}$ was measured immediately. The flavonoid content was expressed as $\mathrm{mg}$ querecitin equivalents /g sample.

\section{Total phenolic content}

$1.0 \mathrm{ml}$ of sample was mixed with $1.0 \mathrm{ml}$ of Folin and Ciocalteu's phenol reagent. After $3 \mathrm{~min}, 1.0 \mathrm{ml}$ of saturated $\mathrm{Na}_{2} \mathrm{CO}_{3}(\sim 35 \%)$ was added to 23 the mixture and made up to $10 \mathrm{ml}$ by adding distilled water. The reaction was kept in the dark for $90 \mathrm{~min}$, observed under UV-Vis spectrophotometer at $760 \mathrm{~nm}$ absorbance. Gallic acid was used as a standard with varied concentration from $200 \mathrm{ppm}$ to $1000 \mathrm{ppm}$. A calibration curve was constructed with different concentrations of tannic acid (0.02- $0.1 \mathrm{mM})$ as standard. The results were expressed as mg of catechol equivalents/g of extract [Morsi RMY et al 2002].

\section{DPPH Free Radical Scavenging Activity}

The free-radical scavenging activities were tested by their ability to bleach the stable radical DPPH. The antioxidant activity using the DPPH (1, 1-diphenyl-2-Picrylhydrazyl) assay was assessed by this method. The sample extracts and standards (BHA and ascorbic acid) were prepared at various concentrations (200-1000 ppm) and mixed with ethanolic solution of DPPH with a concentration of $0.04 \mathrm{mg} / \mathrm{ml}$. After stand for $20 \mathrm{~min}$ in the dark, the mixtures were measured at $517 \mathrm{~nm}$ against ethanol as blank using UV-Vis Spectrophotometer.

The result obtained was calculated using formula:

$$
\text { Scavenging Activity }(\%)=\frac{(\text { Abs Control }- \text { Abs Sample })}{\text { Abs Control } \mathbf{X} 100}
$$

\section{Nitric oxide radical scavenging activity}

The procedure is based on the principle that, sodium nitroprusside in aqueous solution at physiological $\mathrm{pH}$ spontaneously generates nitric oxide which interacts with oxygen to produce nitrite ions that can be estimated using Griess reagent. Scavengers of nitric oxide complete with oxygen, leading to reduced production of nitrite ions. Plant extract was dissolved in distilled water for this quantification. Sodium Nitroprusside $(5 \mathrm{mM})$ in standard phosphate buffer saline $(0.025 \mathrm{~m}, \mathrm{pH} 7.4)$ was incubated with different concentration $(100-400 \mu \mathrm{g} / \mathrm{ml})$ of methanol extract and tubes were incubated at $29^{\circ} \mathrm{C}$ for 3 hours. Control experiment without the test compounds but with equivalent amount of buffer was conducted in an identical manner. After 3 hours incubated samples were diluted with $1 \mathrm{ml}$ of Griess reagents. The absorbance of the colour developed during diazotization of Nitrite with sulphanilamide and its subsequent coupling with Napthylethylenediamine hydro-chloride was observed at $550 \mathrm{~nm}$ on spectrophotometer. Same procedure was done with ascorbic acid which was standard in comparison to methanol extract. Calculated the \% inhibition by formula and plot graph in compared to standard.

$$
\text { Nitric Oxide (\%) }=\left(\mathbf{A}_{\text {control }}-\frac{\left.\mathbf{A}_{\text {test }}\right) \times 100}{\mathbf{A}_{\text {control }}}\right.
$$

Where, $\mathrm{A}_{\text {control }}=$ Absorbance of control reaction $\mathrm{A}_{\text {test }}=$ Absorbance in the presence of the samples of extract.

\section{Total Antioxidant Activity}

Determination of total antioxidant capacity was evaluated by the Phosphomolybdenum method. $0.3 \mathrm{ml}$ of extract and subfraction in ethanol, ascorbic acid used as standard (5 to $200 \mathrm{~g} / \mathrm{ml}$ ) and blank (ethanol) were combined with $3 \mathrm{ml}$ of reagent mixture separately and incubated at $95^{\circ} \mathrm{C}$ for $90 \mathrm{~min}$. After cooling to room temperature, the absorbance of each sample was measured at $695 \mathrm{~nm}$ against the blank. Ascorbic acid was used as standard and the total antioxidant capacity is expressed as equivalents of ascorbic acid or Gallic acid. The antioxidant activity is expressed as the number of equivalents of ascorbic acid and was calculated by the following equation:

$$
\begin{aligned}
& \mathrm{A}=\frac{(\mathrm{c} \times \mathrm{V})}{\mathrm{m}} \text {---------- }(2.2 .2 .3) \\
& \text { Where, }
\end{aligned}
$$




\section{Screening of phytochemicals and bioactive compounds in punica granatum peel to evaluate its hematological potential}

$\mathrm{A}=$ total content of antioxidant compounds, $\mathrm{mg} / \mathrm{g}$ plant extract, in Ascorbic Acid Equivalent,

$\mathrm{c}=$ the concentration of Ascorbic acid established from the calibration curve, $\mathrm{mg} / \mathrm{ml}$,

$\mathrm{V}=$ the volume of extract $(\mathrm{ml})$, and $\mathrm{m}=$ the weight of crude plant extract $(\mathrm{g})$

\section{RESULTS}

Medicinal plants have been exploited continuously by researchers to produce the potent drugs of medicinal properties with reduced toxicity [Kaliyan Barathikannan et al. 2016] The phytochemicals present in the hydroalcoholic extract of pomegranate peel shows the results as shown in Table 1.

\section{Phytochemical Analysis}

Table 1: The phytochemical tests confirm the presence of Carbohydrates which is confirmed by Molisch Test as a violet ring formed at the ring of the two junctions of the liquids. The other tests such as tests for steroids, proteins, alkaloids, tannic acids and phenolic compounds and flavonoids are found to be positive in the peel extracts. Whereas sulphates and chlorides are found absent in this extract.

Table 1

\begin{tabular}{cccc}
\hline S.N. & Phytochemical & Name of Test & Result \\
\hline 1. & Carbohydrates & Molisch test & + \\
2 & Steroids & Salkowiski test & + \\
3 & Proteins & Millions Test & + \\
4 & Alkaloids & Maeyer's test & + \\
5 & Alkaloids & Wagner's Test & + \\
6 & Tannic Acid and & Tannic Acid and Phenolic & + \\
7 & Phenolic compounds & Compounds test & \\
8 & Sulphates & Sulphate Test & - \\
9 & Chlorides & Chloride Test & - \\
\hline
\end{tabular}

\section{DPPH Free Radical Scavenging Activity}

The DPPH radical scavenging activity of Pomegranate peel extract is depicted by the figure 1.Pomegranate fruit peel extract potently scavenged DPPH radicals similar to catechin, it is likely that peelextract possessed proton-donating ability and in association with a number of hydroxyl groups to stabilize free radicals [Al-Zoreky NS.et al 2009, Hajoori M et al.2014].

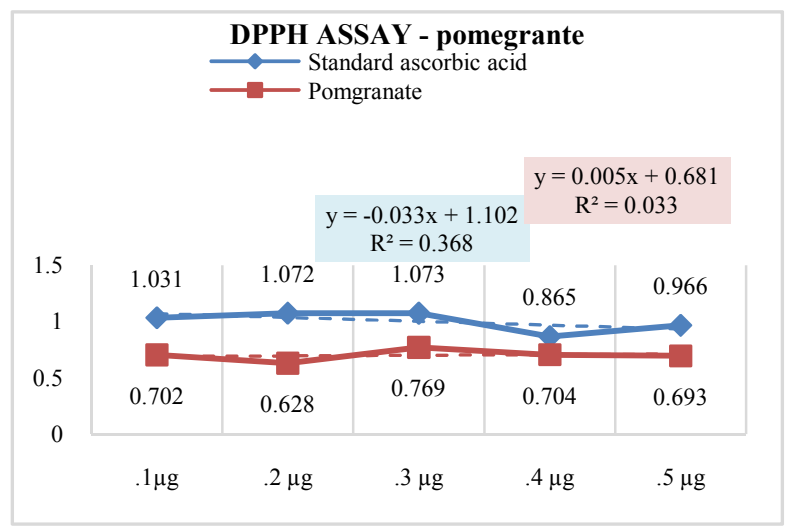

Figure 1 Dpph Assay Pomegrante Peel Extract
The respective values for pomegranate peel are also shown in figure 1 and table 2 .

Table 2 Nitric oxide radical scavenging activity.

\begin{tabular}{ccc}
\hline Concentration & $\begin{array}{c}\text { Standard ascorbic } \\
\text { acid }\end{array}$ & Pomegranate \\
\hline $0.1 \mu \mathrm{g}$ & 1.031 & 0.702 \\
$0.2 \mu \mathrm{g}$ & 1.072 & 0.628 \\
$0.3 \mu \mathrm{g}$ & 1.073 & 0.769 \\
$0.4 \mu \mathrm{g}$ & 0.865 & 0.704 \\
$0.5 \mu \mathrm{g}$ & 0.966 & 0.693 \\
\hline
\end{tabular}

Nitric oxide radical generated from sodium nitroprusside at physiological $\mathrm{pH}$ was found to be inhibited by the peel extracts. The Nitric Oxide scavenging activity is shown in figure 2. The scavenging activity is higher in pomegranate peels as compared to the standard ascorbic acid. From the figure it is clear that with increasing concentration the activity also increases.

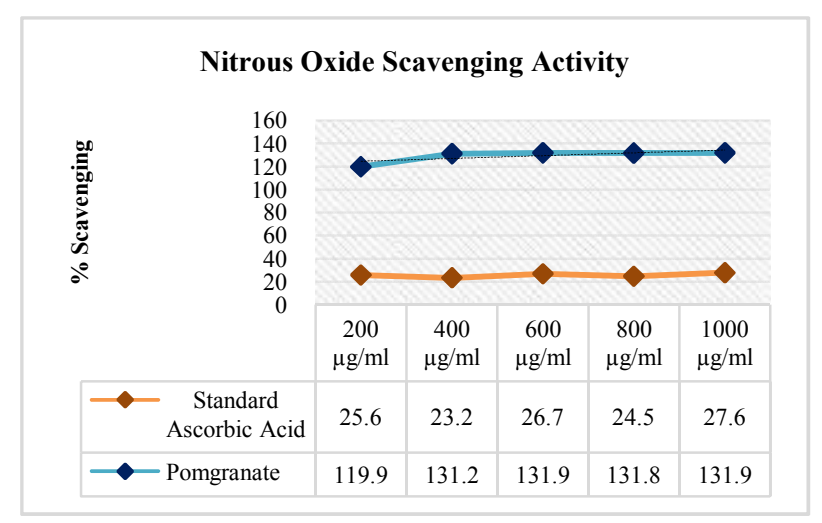

Figure 2 No Scavenging Activity of Pomegrante Peel Extract

\section{Total phenolic content}

The Total Phenolic Content was found to be 273.26 catechol equivalents/g. The results are in agreement to [Singh RP et al 2002] who studied this process for extraction of antioxidants from pomegranate peel extracts but this result differs slightly due to environmental and experimental conditions. The best solvent for the exraction of the phenolic compound is methanol as it has the ability to inhibit the reaction of PPO which leads to the oxidation of phenolics [Yen GC et.al 1994]. The results are shown in figure 2 and table 3.

Table 3 Total Flavonoid content

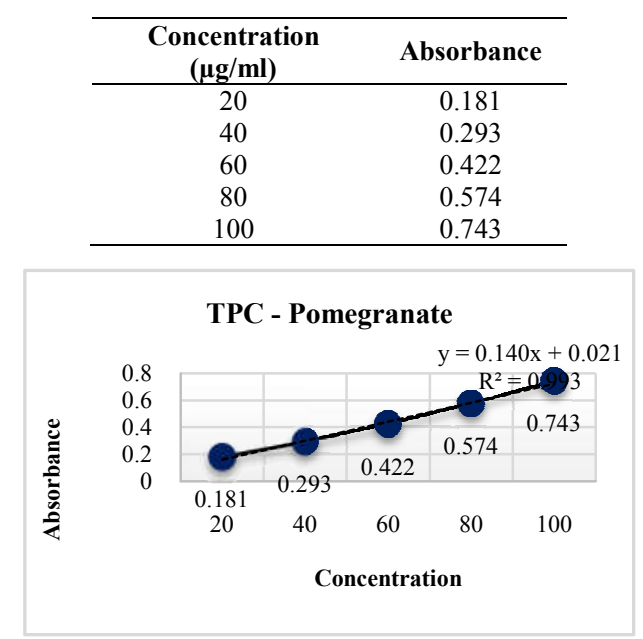

Figure 3 Total Phenolic Contents of Pomegrante Peel Extract 
The total flavanoid content in pomegranate peel extracts were found to be $87.122 \mathrm{mg}$ of quercetin equivalent $/ \mathrm{g}$. The regression coefficient taken here is $\mathrm{R}^{2}=0.990$ and the equation for standard curve is taken as $\mathrm{y}=0.244 \mathrm{x}+0.697$ (figure 4) (table 4).

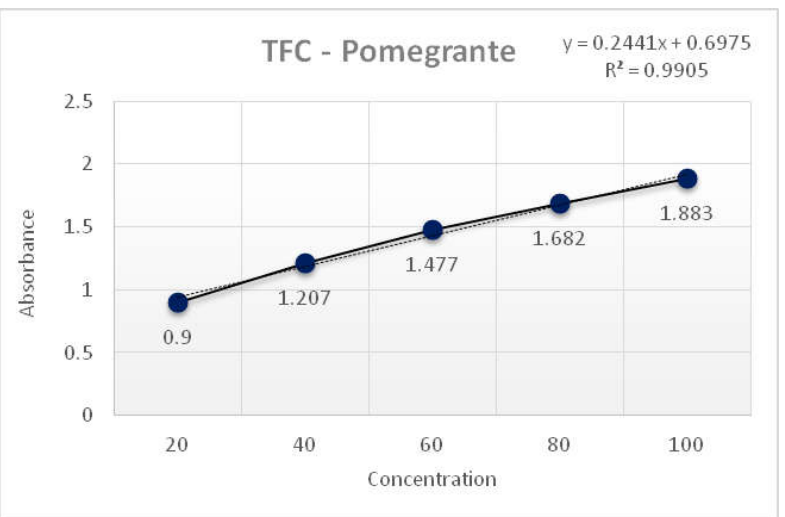

Figure 4 Total Flavanoid Content of Pomegrante Peel Extract

The antioxidant activity of samples was evaluated by the green phosphomolybdenum complex formation according to the method of Prieto (1999). This method is based on the reduction of phosphomolybdic acid to phosphomolybdenum blue complex by sodium sulfide. The obtained phosphomolybdenum blue complex is oxidized by the addition of nitrite and this causes a reduction in intensity of the blue colour. The results shows that at lower concentration the percentage inhibition of pomegranate peel is more as compared to standard ascorbic acid. This is shown in figure 5. P. Granatumpeel extracts can be used as a natural source of antioxidants.

Table 4 Total Antioxidant Activity

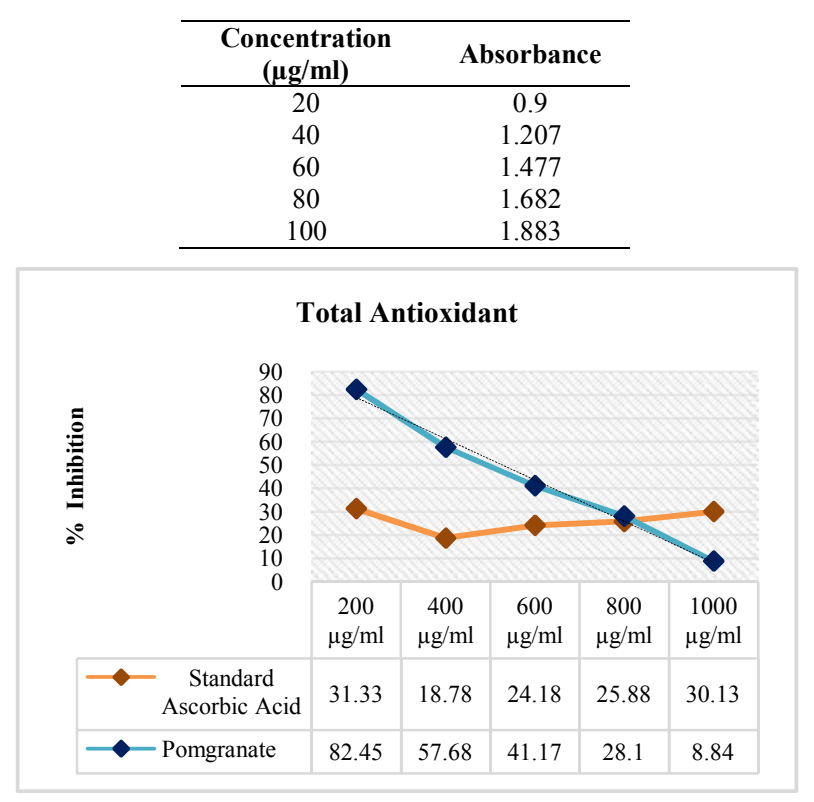

Figure5 Total Antoxidant Activity of Pomegrante Peel Extract

\section{CONCLUSIONS}

Pomegranate has an important role in folk medicine. It is known as a rich source of pharmacological properties. The present study showed interesting preliminary phytochemical constituents in hydroalcoholic peel extracts of Punica granatum. As the pomegranate peel extracts have promising antioxidant properties so these can act as a powerful ingredient in increasing the hemoglobin count. Further characterization and quantitative assay may be carried out to test the peel extracts for various therapeutic and pharmacological activity.

\section{References}

1. Kokate CK, Purohit AP, Gokhale SB. Pharmacognosy. NiraliPrakashan; 2006. 34th ed.:

2. Sharma $\mathrm{J}$ et al Pomegranate Phytochemicals: Nutraceutical and Therapeutic Values, Fruit, Vegetable and Cereal Science and Biotechnology. 29th Oct 2010.

3. Mutahar S, Shibanet.al, Antioxidant Activity of Pomegranate (Punica granatumL.) Fruit Peels, Food and Nutrition Sciences. 2012; 3:991-996.

4. Huang DO and Prior BR, "The Chemistry behind Antioxidant Capacity Assays." Journal of Agriculture and Food Chemistry. 2005; Vol. 53; No. 6:1841-1856.

5. Balasundram N, Sundram K And Samman S. "Phenolic Compounds in Plants and Agri-Industrial By-Products: Antioxidant Activity, Occurrence, and Potential Uses." Food Chemistry. 2006;Vol. 99, No1 :191-203.

6. Reddy M, Gupta S, Jacob M, Khan S and Ferreira D, "Antioxidant, Antimalarial and Antimicrobial Activities of Tannin-Rich Fractions, Ellagitannins and Phenolic Acids from Punica granatum L." Planta Medica. 2007; Vol. 73, No. 5: 461-467.

7. Li Y, Guo C, Yang J, Wei J, Xu J and Cheng S, "Evaluation of Antioxidant Properties of Pomegranate Peel Extract in Comparison with Pomegranate Pulp Extract." Food Chemistry. Vol. 96, No. 2, 2006. pp. 254-260.

8. Reddy M, Gupta S, Jacob M, Khan S and Ferreira D, "Antioxidant, Antimalarial and Antimicrobial Activities of Tannin-Rich Fractions, Ellagitannins and Phenolic Acids from Punica granatum L." Planta Medica. Vol. 73; No. 5, 2007: 461-467.

9. Iqbal S, Haleem S, Akhtar M, Zia-ul-Haq M and Akbar J, "Efficiency of Pomegranate Peel Extracts in Stabilization of Sunflower Oil under Accelerated Conditions." Food Research International;Vol. 41, No. 2, 2008: pp. 194-200.

10. Negi $P$ and Jayaprakasha J. "Antioxidant and Antibacterial Activities of Punica granatum Peel Extracts." Journal of Food Science. Vol. 68, No. 4, 2003:pp. 1473-1477.

11. Murthy KC, Jayaprakasha $G$ and Singh R. "Antioxidant Activity of Pomegranate Peel Extracts in Vivo Models." Journal of Agriculture and Food Chemistry. Vol. 50; No. 17, 2002:pp. 4791-4795.

12. Iqbal S, Haleem S, Akhtar M, Zia-ul-Haq $M$ and Akbar J. "Efficiency of Pomegranate Peel Extracts in Stabilization of Sunflower Oil under Accelerated Conditions." Food Research International. Vol. 41; No. 2, 2008, pp. 194-200.

13. Surya Prabha M, Santhosh Aruna M, Gulshan MD, Laxshmi Prasanna J, Rama Rao N. "Preliminary And Pharmacognostic Investigation On Leaves Of Punica Granatum".Int.Res.J.Pharm.2013:4(12).

14. Olaleye MT. "Cytotoxicity and antibacterial activity of methanolic extracts of Hibiscus Sabdariffa." Journal of Medicinal Plants Research. 2007;1:9-13. 
15. Brain FH, Thomas Bigger J, Goodman G. "The Pharmacological Basis of Therapeutics." MacMillan, New York: NY, USA; 1985.p.7.

16. Ayoola GA, Coker HAB, Adesegun SA, Adepoju Bello AA, Obaweya K, Ezennia EC, Atangbayila TO. "Phytochemical screening and antioxidant activities of some selected medicinal plants used for malaria therapy in southwestern Nigeria." Trop J Pharma Res. 2008; 7(3):1019-1024.

17. Morsi RMY, Tahan NREL, El-Hadad AMA. "Effect of aqueous extract Mangifera Indica leaves, as functional foods." J ApplSci Res. 6: 712.

18. Singh RP, Murthy KNC, Jayaprakasha GK (2002) Studies on the antioxidant activity of pomegranate (Punica granatum) peel and seed extracts using in vitro models. J Agric Food Chem. 50: 81-86.

19. Yen GC, Chen HY. "Comparison of antimutagenic effect of various tea extracts (green, oolong, pouchong and black tea)". Journal of Food Protection. 1994; 57 : 54-58.
20. Kaliyan Barathikannan et.al. "Chemical Analysis of Punica granatum fruit peel and its in vitro and in vivo biological properties". BMC Complementary and Alternative Medicine 2016;16:264.

21. Al-Zoreky NS. Antimicrobial activity of pomegranate (Punicagranatum L.) fruit peels. Int J Food Microbiol. 2009; 134(3):244-8.

22. Hajoori $\mathrm{M}$ et al. Punica granatum peel extracts using different solventsystem. Int J Pharmacol Screen Methods. 2014; 4(1):26-31

23. Hemoglobin increase naturally Ayurveda Tips,ayur tips $\cdot$ published November 18, 2016.Updated december 1,2016

24. http://healthforeversupplements.blogspot.in/2010/02/i mprove-blood-quality-lower-blood.html.Wednesday, February 10, 2010

\section{How to cite this article:}

Savita Dixit et al(2017) ' Screening of phytochemicals and bioactive compounds in punica granatum peel to evaluate its hematological potential', International Journal of Current Advanced Research, 06(03), pp. 2524-2529. DOI: http://dx.doi.org/10.24327/ijcar.2017.2529.0042 